\title{
Keterampilan Menulis Karangan Persuasi Siswa Dalam Pembelajaran Think Talk Write dengan Media Poster
}

\author{
Wilda Ayu Hajar Octavia \\ Universitas Jember \\ wildayuhajaroctavia11@gmail.com
}

\section{Hari Satrijono}

Universitas Jember hsatrijono@gmail.com

\section{Fajar Surya Hutama}

Universitas Jember

fajarsurya.fkip@unej.ac.id

\section{Dimas Abdi Haidar}

Universitas Negeri Malang

dimashaidar147@gmail.com

\section{Linda Purnamasari Rukmana}

Universitas Jember

Lindapur1988@gmail.com

\begin{abstract}
Writing is a complex skill and is difficult for students to master well. This study aims to determine the effect of the application of Think Talk Write learning models with poster media on the writing skills of persuasion essay from fifth grade elementary school students. This type of research is a quasi-experimental design with a pre-test post-test control group. The sample in this study was VA and V class students of SDN Rambigundam 01 Jember. Collecting data in this study using interviews, tests, and documentation. The data analysis technique of student learning outcomes uses t-test. Based on the results of the t-test on the learning outcomes of students' persuasive essay writing skills, it is known that the value of tcount> ttable, (2.208>2.0180), so it can be concluded that the hypothesis is accepted that the Think Talk Write learning model through poster media influences the writing skills of persuasion writing in the fifth grade students of SDN Rambigundam Jember 1. The results of the pretest and posttest
\end{abstract}


Wilda Ayu Hajar Octavia, Hari Satrijono, Fajar Surya Hutama, Dimas Abdi Haidar, Linda Purnamasari Rukmana

Keterampilan Menulis Karangan Persuasi Siswa Dalam Pembelajaran Think Talk Write

activities also showed that the increase in the value of writing skills written by students in the experimental class was higher than the increase experienced by the control class. Difference in the increase in the average value experienced by the experimental class and control class by 3,7.

Keywords: Think Talk Write; Poster Media; Persuasive Essay

\begin{abstract}
Abstrak
Menulis merupakan salah satu keterampilan yang kompleks dan sulit dikuasai siswa dengan baik. Penelitian ini bertujuan untuk mengetahui pengaruh penerapan model pembelajaran Think Talk Writedengan media poster terhadap keterampilan menulis karangan persuasi siswa kelas V SD. Jenis penelitian ini merupakan eksperimen semu dengan desainpre-test posttest control group. Sampel dalam penelitian ini adalah siswa kelas VA dan V B SDN Rambigundam 01 Jember. Pengumpulan data dalam penelitian ini menggunakan metode wawancara, tes, dan dokumentasi. Teknik analisisdata hasil belajar siswa menggunakan uji t-test. Berdasarkan hasil uji-t terhadap hasil belajar keterampilan menulis karangan persuasif siswa, diketahui bahwa nilai $t_{\text {hitung }}>t_{\text {tabel }},(2,208>2,0180)$, sehingga dapat disimpulkan bahwa hipotesis diterima yaitu model pembelajaran Think Talk Write melalui media poster berpengaruh terhadap keterampilan menulis karangan persuasi pada siswa kelas V SDN Rambigundam 01 Jember. Hasil kegiatan pretest dan posttest juga menunjukan bahwa peningkatan nilai keterampilan menulis karangan siswa di kelas eksperimen lebih tinggi dari pada peningkatan yang dialami kelas kontrol. Selisih peningkatan rata-rata nilai yang dialami kelas eksperimen dan kelas kontrol sebesar 3,7.
\end{abstract}

Kata Kunci: Think Talk Write; Media Poster; Karangan Persuasi 


\section{PENDAHULUAN}

Bahasa berperan penting dalam perkembangan aspek kognitif, afektif, dan psikomotor siswa serta sebagai sarana penunjang ketercapaian dalam mempelajari semua bidang studi. Pemahaman penggunaan bahasa dapat mempermudah siswa dalam menerima maupun menyampaikan informasi khususnya dalam proses pembelajaran. Seharusnya pembelajaran Bahasa Indonesia di SD perlu diberikan dengan mengkreasikan model pembelajaran yang tepat, supaya siswa memahami keterampilan berbahasa secara optimal khususnya keterampilan menulis karangan persuasi, sehingga kompetensi yang diharapkan dapat tercapai.

Berdasarkan Kurikulum Tingkat Satuan Pendidikan (KTSP) mata pelajaran Bahasa Indonesia SD kelas V Semester 1, Standar Kompetensi (SK) yang harus dicapai siswa pada keterampilan menulis adalah mengungkapkan pikiran, perasaan, informasi, dan pengalaman secara tertulis dalam bentuk karangan, surat undangan, dan dialog tertulis, sedangkan Kompetensi Dasar (KD) yang harus dicapai adalah menulis karangan berdasarkan pengalaman dengan memperhatikan pilihan kata dan penggunaan ejaan ${ }^{1}$. Ruang lingkup mata pelajaran Bahasa Indonesia digolongkan menjadi dua bentuk komunikasi, yaitu komunikasi lisan dan komunikasi tulis. Komunikasi lisan meliputi keterampilan menyimak dan berbicara, sedangkan komunikasi tulis meliputi keterampilan membaca, dan menulis. Salah satu keterampilan berbahasa yang harus dimiliki dan dikuasai siswa adalah keterampilan menulis.

Keterampilan menulis karangan merupakan keterampilan dalam menyampaikan informasi, gagasan, dan pikiran ke bentuk tulisan, sehingga dengan menulis siswa dapat mengungkapkan ide atau pendapat, pikiran dan perasaannya, serta dapat mengembangkan kreativitas siswa dalam

\footnotetext{
${ }^{1}$ Badan Standar Nasional Pendidikan, Kurikulum Tingkat Satuan Pendidikan Sekolah Dasar, (Jakarta: Badan Standar Nasional Pendidikan (BSNP), Departemen Pendidikan Nasional, 2006), 129.
} 
Wilda Ayu Hajar Octavia, Hari Satrijono, Fajar Surya Hutama, Dimas Abdi Haidar, Linda Purnamasari Rukmana

Keterampilan Menulis Karangan Persuasi Siswa Dalam Pembelajaran Think Talk Write

menulis ${ }^{2,3,4}$. Keterampilan menulis merupakan keterampilan berbahasa yang paling kompleks dan sangat penting sebagai penunjang keberhasilan proses belajar-mengajar, karena menulis merupakan keterampilan menuangkan dan mengembangkan ide atau gagasan dari hasil proses menyimak, berbicara, ataupun membaca.Namun pada kenyataanya banyak siswa yang tidak memiliki keterampilan menulis yang baik pada jenjang kelas rendah bahkan sampai kelas tinggi. Hasil observasi pra-penelitian terdahulu mengungkapkan bahwa sebagian besar siswa SD mengalami kesulitan dalam menulis karangan dan memiliki nilai keterampilan menulis yang rendah $^{5,6}$. Oleh karena itu, dalam melatih keterampilan menulis siswa hendaknya diberikan kesempatan, latihan dan pengalaman secara langsung, bukan hanya melalui teori.

Berdasarkan hasil observasi di lapangan, dapat diketahui bahwa masih banyak siswa yang kurang mampu dalam mengembangkan kreativitas dan imajinasinya untuk menuangkan gagasannya ke dalam bentuk tulisan, sehingga siswa cenderung bingung tantang apa yang hendak ditulis dalam sebuah karangan. Hasil observasi juga menunjukan bahwa model pembelajaran yang diterapkan guru kurang efektif dalam membangun keterampilan menulis siswa. Dalam pembelajaran bahasa Indonesia guru kelas cenderung menyajikan materi-materi dan menunjukan contoh-contoh kalimat atau teks bacaan saja tanpa berusaha memfasilitasi siswa untuk memahami materi dan mempraktikannya secara mandiri. Menurut Haidar,

\footnotetext{
${ }^{2}$ Tarigan, H, Menulis sebagai suatu Keterampilan Berbahasa, (Bandung: Penerbit Angkasa, 1994).

${ }^{3}$ Satrijono, H, Keterampilan Berbahasa Indonesia SD, (Jember: Fakultas Keguruan dan Ilmu Pendidikan Universitas Jember, 2011).

${ }^{4}$ A. Susanto, Teori Belajar dan Pembelajaran di Sekolah Dasar, (Jakarta: Kencana Prenada Media Group, 2015).

${ }^{5}$ Aryananda, J., Chamistijatin, L., \& Hafi, A, Penerapan Model Think Talk Writeuntuk Meningkatkan Keterampilan Menulis Kalimat Efektif pada Siswa Kelas III SDN Sumbersari 1 Kota Malang, Jurnal Basicedu, (Vol. 3. No.1, 2019), 119.

${ }^{6}$ Dery, D. W., Pebriana, P. H., \& Putra, K. E, Penerapan Model Kooperatif Tipe Think Talk Writeuntuk Meningkatkan Keterampilan Menulis Karangan Narasi Pada Siswa Sekolah Dasar, Jurnal Pendidikan dan Konseling, (Vol. 1. No.1, 2019), 3.
} 
guru hendaknya merubah pola mengajar dari yang awalnya berperan sebagai sumber utama menjadi seorang fasilitator yang diharuskan mampu membimbing siswa untuk dapat aktif, produktif, kreatif, dan inovatif dalam pembelajaran ${ }^{7}$.

Dengan demikian, perlu diterapkan cara belajar yang memberi kebebasan kepada siswa, sehingga siswa dapat menerapkan pengetahuannya secara mandiri untuk lebih produktif. Selain itu, perlu adanya rancangan pembelajaran yang mampu mengaktifkan kelas dan membantu siswa dalam mengembangkan imajinasinya, diantaranya dengan cara mengoordinasikan siswa dalam beberapa kelompok belajar serta menggunakan media pembelajaran yang sesuai dengan materi pembelajaran. Kelompok belajar sebaiknya dibagi secara heterogen, yaitu dalam setiap kelompok memiliki anggota dengan tingkat intelektual yang berbeda-beda, hal ini dapat mempermudah siswa dalam menyelesaikan tugas belajarnya. Selanjutnya, penggunaan media pembelajaran diharapkan dapat membantu siswa dalam mengembangkan imajinasinya yang hendak disampaikan dalam bentuk tulisan. Oleh karena itu, media pembelajaran yang dianggap sesuai adalah media poster. Media poster memiliki warna, desain yang menarik, serta tulisan yang ringkas dan mudah dipahami, sehingga dapat membantu siswa dalam mengembangkan imajinasinya.

Salah satu model pembelajaran yang mampu mengaktifkan siswa untuk belajar bersama-sama adalah model pembelajaran kooperatif. Menurut Slavin, model pembelajaran kooperatif merupakan model pembelajaran yang menempatkan siswa sebagai penanggung jawab terhadap keberhasilan kelompoknya, sehingga terjadi kerjasama, sikap terbuka, dan saling membantu ${ }^{8}$. Terdapat beberapa model pembelajaran kooperatif, salah satunya adalah model pembelajaran kooperatif tipe Think Talk Write yang

${ }^{7}$ Haidar, D. A., Hasanah, S. A. \& Hutama, F. S, Analyzing Elementary Teacher's Understanding Towards Learning Instrument of 2013 Curriculum at SDN Sumbersari 1, Jember, Pancaran Pendidikan, (Vol. 6, No. 2, 2017), 15.

${ }^{8}$ Yusron, Cooperative Learning, (Bandung: Nusa Media, 2005), 10. 
Wilda Ayu Hajar Octavia, Hari Satrijono, Fajar Surya Hutama, Dimas Abdi Haidar, Linda Purnamasari Rukmana

Keterampilan Menulis Karangan Persuasi Siswa Dalam Pembelajaran Think Talk Write

lebih sesuai jika digunakan dalam mengatasi masalah terhadap kemampuan menulis siswa. Model pembelajarn Think Talk Write ini dapat membantu siswa dalam mengembangkan gagasannya dan siswa memiliki kebebasan untuk merekonstruksi pengetahuannya secara mandiri ${ }^{9}$. Selain itu, siswa berkesempatan untuk bertukar pendapat dengan kelompoknya, sehingga terjadi kerjasama dan saling membantu. Selanjutnya, siswa bebas menuliskan hasil diskusinya dalam bentuk karangan sesuai dengan imajinasi setiap siswa.

Model pembelajaran Think Talk Write yaitu model pembelajaran yang memberikan kebebasan pada siswa untuk merekonstruksi pengetahuannya sendiri serta memberikan kesempatan untuk menuangkan ide-ide atau gagasannya dalam bentuk lisan secara berkelompok, kemudian secara individu siswa bebas mengembangkan hasil diskusinya dalam bentuk tulisan. Model pembelajaran Think Talk Write memiliki tiga komponen utama yang meliputi think (berpikir), talk (berbicara), dan write (menulis). Think (berpikir), dapat terlihat melalui aktivitas siswa dalam memahami suatu bahan pelajaran, dalam hal ini siswa mencatat hal-hal penting yang diketahui ataupun tidak diketahuinya. Talk (berbicara), pada tahap ini siswa dilatih untuk terampil dalam berbicara melalui kebebasan dalam mengungkapkan gagasannya terhadap kelompok yang heterogen. Write (menulis), setelah melakukan diskusi aktivitas selanjutnya adalah menuangkan hasil diskusi dalam bentuk tulisan secara individu. ${ }^{10}$

Aktivitas guru dalam model pembelajaran Think Talk Write yaitu sebagai fasilitator dan motivator. Sebagai fasilitator, guru harus mampu memberikan arahan maupun bimbingan terhadap setiap siswa yang mengalami kesulitan. Begitu juga sebagai motivator, bahwa guru harus dapat memberikan semangat kepada siswa yang kurang percaya diri agar

\footnotetext{
${ }^{9}$ Ibid

${ }^{10}$ Hamdayama, J, Model dan Metode Pembelajaran Kreatif dan Berkarakter, (Bogor: Ghalia Indonesia, 2014), 218.
} 
proses pembelajaran berjalan aktif. Penerapan model pembelajaran Think Talk Write diharapkan lebih berhasil dalam mengembangkan keterampilan menulis siswa jika disertai dengan penggunaan media pada proses pembelajaran. Hasil penelitian terdahulu menyatakan bahwa penerapan model pembelajaran TTW di dalam kelas mampu meningkatkan keaktifan dan hasil belajar siswa secara signifikan ${ }^{11,12}$.Oleh karena itu, penelitian ini akan menerapkan model pembelajaran Think Talk Write melalui media poster. Penggunaan media poster dimaksudkan untuk membantu siswa dalam mengembangkan imajinasinya. Media poster dapat mempermudah pemahaman siswa, karena pesan yang disampaikan jelas, singkat, dan mudah dipahami, dan memiliki desain yang menarik, sehingga dapat mempermudah siswa dalam berimajinasi. Berdasarkan permasalahan yang ada, maka dibutuhkan penelitian dengan judul " Pengaruh Penerapan Model Pembelajaran Think Talk Write melalui Media Poster terhadap Hasil Belajar Bahasa Indonesia pada Siswa Kelas V SD ”.

\section{METODE PENELITIAN}

Penelitian ini menggunakan jenis penelitian eksperimen, yaitu dengan cara memberikan perlakuan dan mengetahui ada atau tidaknya pengaruh penerapan model pembelajaran Think Talk Write melalui media poster terhadap keterampilan menulis karangan persuasi pada siswa kelas V SD terhadap kelas eksperimen. Sebagai pembanding, terdapat kelas kontrol yang melaksanakan pembelajaran tanpa penerapan model pembelajaran Think Talk Write melalui media poster. Penentuan sampel penelitian dengan metode cluster random sampling.

${ }^{11}$ Rizal, M. S, Pengaruh Model Pembelajaran Kooperatif Tipe Think Talk Write (TTW) Terhadap Keaktifan dalam Pembelajaran IPS Kelas V SDN 20 Kuok, Jurnal Basicedu, (Vol. 2 No.1, 2018), 111.

${ }^{12}$ Ryanti, W. O. Penerapan Model Pembelajaran Think Talk Write (TTW) Untuk Meningkatkan Aktivitas dan Hasil Belajar Siswa Kelas V Pada Mata Pelajaran IPS SD Negeri 9 Metro Timur Tahun Pelajaran 2015/2016. Skripsi, (Lampung: FKIP Universitas Lampung 2016). 
Wilda Ayu Hajar Octavia, Hari Satrijono, Fajar Surya Hutama, Dimas Abdi Haidar, Linda Purnamasari Rukmana

Keterampilan Menulis Karangan Persuasi Siswa Dalam Pembelajaran Think Talk Write

Sampel dalam penelitian ini adalah siswa kelas VA dan V B SDN Rambigundam 01 Jember semester ganjil tahun pelajaran 2017-2018. Desain penelitian ini menggunakan desainpre-test post-test control group, apabila digambarkan dalam diagram sebagai berikut.

$$
\begin{array}{cccc}
\mathrm{E} & : \mathrm{O} 1 & \mathrm{X} & \mathrm{O} 2 \\
\mathrm{C} & \mathrm{O} 1 & & \mathrm{O} 2 \\
\hline
\end{array}
$$

Keterangan:

$\mathrm{E} \quad=$ Kelompok eksperimen

$\mathrm{C} \quad=$ Kelompok kontrol

O1 = Tes awal yang diberikan pada kelas eksperimen dan kelas kontrol

$\mathrm{X}=$ Perlakuan yang diberikan pada kelas eksperimen

O2 = Tes akhir yang diberikan pada kelas eksperimen dan kelas kontrol dengan instrumen yang sama seperti pada tes awal ${ }^{13}$.

Metode pengumpulan data dalam penelitian ini berupa wawancara, observasi, dan tes. Kegiatan wawancara dan observasi dilakukan menggunakan instrumen pedoman wawancara dan instrumen pedoman observasi terhadap guru dan siswa untuk mengetahui gambaran kondisi awal proses pembelajaran muatan Bahasa Indonesia yang biasa dilaksanakan. Kegiatan tes diberikan sebanyak dua kali di setiap kelas yaitu pretest dan posttest menggunakan instrumen menulis karangan narasi untuk mengukur kemampuan menulis karangan narasi persuasi siswa. Instrumen tes menulis karangan narasi siswa berupa 3 soal unjuk kerja yang meminta siswa membuat karangan narasi persuasi berdasarkan beberapa gambar poster yang diberikan. Aspek yang dinilai dalam karangan narasi persuasi siswa meliputi: (1) isi gagasan yang dikemukakan; (2) organisasi isi; (3) diksi/pilihan kata; (4) ejaan dan tanda baca.

${ }^{13}$ Masyhud, M. S, Metode Penelitian dan Pendidikan, (Jember: Lembaga Pengembangan Manajemen dan Profesi Kependidikan, 2014), 154. 
Teknik analisis data dalam penelitian ini menggunakan analisis statistik t-test dengan data hasil belajar keterampilan menulis karangan narasi persuasi menggunakan bantuan SPSS 17.0. Ketentuan uji hippotesis t-testadalah: (1) jika $\mathrm{t}>0,05$ maka $\mathrm{H}_{0}$ ditolak dan $\mathrm{H}_{\mathrm{a}}$ diterima; (2) jika $\mathrm{t}>$ 0,05 maka $\mathrm{H}_{0}$ diterima dan $\mathrm{H}_{\mathrm{a}}$ ditolak.

\section{HASIL DAN PEMBAHASAN TEMUAN HASIL TEMUAN}

Penelitian ini menggunakan jenis penelitian eksperimen semu dengan desainpre-test post-test control group yang bertujuan untuk mengetahui ada atau tidaknya pengaruh penerapan model pembelajaran Think Talk Write melalui media poster terhadap keterampilan menulis karangan persuasi pada siswa kelas V SDN Rambigundam 01 Jember. Penelitian ini dilaksanakan pada kelas VA yang berjumlah 21 siswa dan VB yang berjumlah 23 siswa. Penentuan kelas tersebut berdasarkan hasil uji homogenitas pada kedua kelas dengan menggunakan nilai Ulangan Tengah Semester (UTS) Bahasa Indonesia yang menunjukan bahwa siswa pada kelas VA dan VB mempunyai kemampuan yang homogen. Uji homogenitas dalam penelitian ini dilakukan menggunakan SPSS 17.0 dengan taraf signifikansi 5\%. Berdasarkan hasil uji homogenitas yang telah dilakukan, diketahui bahwa $\mathrm{t}_{\text {hitung }}=0.526$ nilainya lebih kecil dari pada $\mathrm{t}_{\text {tabel }}=2.0085$, sehingga kedua kelas dinyatakan memiliki kemampuan homogen. Selanjutnya penentuan kelas kontrol dan kelas eksperimen menggunakan teknik cluster sampling dengan teknik undian. Adapun hasilnya yaitu kelas V A sebagai kelas eksperimen dan kelas V B sebagai kelas kontrol.

Sebelum perlakuan diberikan pada kedua kelas, terlebih dahulu dilakukan pre-test untuk mengetahui kemampuan awal siswa dalam menulis karangan narasi persuasi. Soal dalam kegiatan pre-test menuntut siswa membuat karangan persuasi berdasarkan gambar poster bertema 
Wilda Ayu Hajar Octavia, Hari Satrijono, Fajar Surya Hutama, Dimas Abdi Haidar, Linda Purnamasari Rukmana

Keterampilan Menulis Karangan Persuasi Siswa Dalam Pembelajaran Think Talk Write

"kesehatan". Selanjutnuya, kelas eksperimen (VA) diberi perlakuan menggunakan model pembelajaran Think Talk Write melalui media poster, sedangkan kelas kontrol (VB) diberi perlakuanmenggunakanpembelajaran konvensional atau yang biasa diterapkan sehari-hari. Penerapan model pembelajaran Think Talk Write melalui media poster bertujuan agar siswa dengan mudah mengembangkan imajinasinya dan membantu siswa dalam menuangkan serta mengembangkan idenya dalam bentuk karangan persuasi. Setelah pemberian perlakuan, dilaksanakan post-test dengan instrumen tes yang sama dengan kegiatan pre-test. Selanjutnya data hasil karangan narasi persuasi siswa diberi skor dan dianalisis untuk menentukan peningkatan keterampilan menulis karangan narasi persuasi di kelas eksperimen dan kelas kontrol. Ringkasan hasil analisis keterampilan menulis karangan narasi persuasi siswa pada kegiata pre-test dan post-test di kelas eksperimen dan kelas kontrol disajikan pada Tabel berikut.

Tabel 1. Ringkasan keterampilan menulis karangan persuasi siswa

\begin{tabular}{lccc}
\hline \multicolumn{1}{c}{ Kelas } & pretest & posttest & Selisih \\
\hline Kelas eksperimen (VA) & 59,45 & 70,76 & 11,31 \\
\hline Kelas Kontrol (VB) & 59,24 & 66,85 & 7,61 \\
\hline
\end{tabular}

Untuk mengetahui perbedaan pengaruh model pembelajaran Think Talk Write melalui media poster terhadap keterampilan menulis karangan narasi persuasi siswa dilakukan analisis data berupa uji-t. Data yang digunakan untuk uji-t adalah hasil tes keterampilan menulis karangan narasi persuasi siswa. Ringkasan hasil uji-t menggunakan SPSS 17.0 dimuat dalam Tabel berikut. 
Tabel 2. Ringkasan Hasil Uji-t

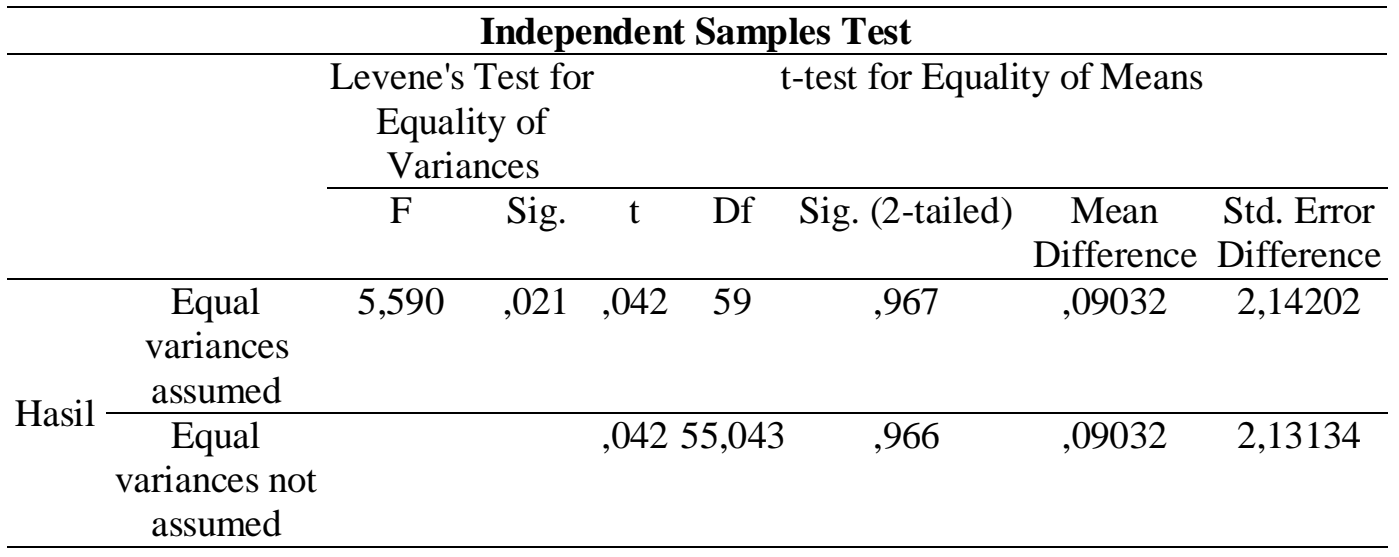

Berdasarkan hasil uji-t pada Tabel 2, diperoleh $t_{\text {hitung }}=2,208$. Nilai tersebut kemudian dikonsultasikan pada $t_{\text {tabel }}$ dengan nilai $t_{\text {tabel }}$ pada jumlah siswa 42 (2,0180). Adapun kriteria pengujian hasil uji-t adalah apabila $t_{\text {hitung }}>t_{\text {tabel }}$ maka $\mathrm{H}_{0}$ ditolak dan $\mathrm{H}_{\mathrm{a}}$ diterima, sedangkan jika $\mathrm{t}_{\text {hitung }}>\mathrm{t}_{\text {tabel }}$ maka $\mathrm{H}_{0}$ diterima dan $\mathrm{H}_{\mathrm{a}}$ ditolak. Nilai $\mathrm{t}_{\text {hitung }}$ pada tabel 2 menunjukan bahwa $t_{\text {hitung }}>t_{\text {tabel }}(2,208>2,0180)$, sehingga $H_{a}$ diterima dan dapat disimpulkan bahwa terdapat pengaruh yang signifikan penerapan model pembelajaran Think Talk Write melalui media poster dengan keterampilan menulis karnagan persuasi pada siswa kelas V SDN Rambigundam 01 Jember.

\section{PEMBAHASAN TEMUAN}

Berdasarkan hasil penelitian ini, penggunaan model pembelajaran kooperatif melalui media poster terbukti dapat membantu siswa dalam mengembangkan imajinasinya serta meningkatkan interaksi antar siswa dalam kelompok. Model pembelajaran kooperatif yang digunakan adalah model pembelajaran kooperatif tipe Thik Talk Write.Model pembelajaran Think Talk Write merupakan model pembelajaran kooperatif yang menghendaki terbentuknya kegiatan belajar secara berkelompok. Model pembelajaran Think Talk Write dianggap lebih sesuai apabila digunakan 
Wilda Ayu Hajar Octavia, Hari Satrijono, Fajar Surya Hutama, Dimas Abdi Haidar, Linda Purnamasari Rukmana

Keterampilan Menulis Karangan Persuasi Siswa Dalam Pembelajaran Think Talk Write

untuk mengembangkan keterampilan menulis siswa. Model pembelajaran ini memiliki tiga tahap dalam penerapannya, diantaranya Think, Talk, dan Write $^{14}$. Tahap pertama yaitu Think, siswa secara individu diminta untuk menemukan dan mencatat ide pokok dari sebuah poster yang diterima. Selanjutnya guru membagi siswa dalam beberapa kelompok, setiap kelompok terdiri dari 4-5 siswa, setelah pembagian kelompok dilanjutkan dengan proses diskusi (Talk), siswa mendiskusikan ide pokok yang telah dicatatnya pada tahap Think bersama kelompoknya, diskusi merupakan kegiatan yang dilakukan untuk memecahkan masalah secara berkelompok ${ }^{15}$. Tahap ketiga yaitu Write, pada tahap ini siswa secara individu menuliskan hasil diskusinya yang berupa ide pokok dari sebuah poster ke dalam bentuk karangan persuasi.

Karangan persuasi merupakan karangan yang bertujuan untuk mempengaruhi pembaca agar mengikuti perintah atau ajakan yang disampaikan ${ }^{16,17}$. Oleh karena itu, siswa harus mampu menuliskan dan mengembangkan ide atau gagasannya dalam suatu karangan yang bersifat mengajak. Penerapan model pembelajaran Think Talk Write pada penelitian ini disertai dengan penggunaan media pembelajaran. Media pembelajaran yang digunakan adalah media poster.

Media pembelajaran merupakan segala bentuk alat ataupun bahan pembelajaran yang digunakan sebagai perantara untuk menyampaikan informasi dari guru kepada siswa atau sebaliknya ${ }^{18,19}$. Salah satu media pembelajaran yang dapat membantu siswa dalam mengembangkan

\footnotetext{
${ }^{14}$ Hamdayama, J, Model dan Metode Pembelajaran Kreatif dan Berkarakter, (Bogor: Ghalia Indonesia, 2014), 218.

15 Tarigan, H, Menulis sebagai suatu Keterampilan Berbahasa, (Bandung: Penerbit Angkasa, 1994), 36.

${ }^{16}$ Keraf, G. Argumentasi dan Narasi, (Jakarta: Gramedia Pustaka Utama, 2000).

${ }^{17}$ Suparno, Keterampilan Dasar Menulis, (Jakarta: Departemen Pendidikan Nasional Universitas Terbuka, 2008).

${ }^{18}$ Sadiman, Media Pendidikan, (Jakarta: Rajawali Pers, 2010)

${ }^{19}$ Siddiq, dkk, Pengembangan Bahan Pembelajaran SD, (Jakarta: Direktorat Jenderal Pendidikan Tinggi Departemen Pendidikan Nasional, 2008).
} 
imajinasinya adalah media poster. Media poster merupakan media pembelajaran yang berupa sebuah gambar dengan ukuran yang cukup besar, warna menarik, serta berisi pesan yang lugas dan ringkas ${ }^{20}$. Oleh karena itu, dengan ciri-ciri yang dimiliki oleh sebuah poster diharapkan media poster dapat membantu siswa dalam mengembangkan imajinasinya serta membantu siswa dalam menuangkan gagasannya dalam bentuk tulisan. Berdasarkan Kompetensi Dasar (KD) Kelas V SD, bahwasannya keterampilan menulis merupakan salah satu keterampilan berbahasa yang harus dimiliki oleh siswa kelas V SD dengan memperhatikan ejaan dan tanda baca.

Keterampilan menulis merupakan keterampilan siswa mengungkapkan ide atau gagasannya ke dalam bentuk tulisan. Menulis merupakan kegiatan yang memerlukan latihan dan pengalaman secara langsung, dalam menulis siswa harus dapat memilih dan memilah kata agar tulisan dapat dipahami oleh pembaca. Terdapat tiga langkah dalam menulis, yaitu tahap prapenulisan yaitu kegiatan awal dalam menulis berupa penentuan topik tulisan. Kedua, tahap penulisan merupakan kegiatan menguraikan kerangka karangan menjadi karangan utuh. Ketiga, pasca penulisan merupakan kegiatan penyuntingan atau revisi hasil karangan ${ }^{21,22}$. Pada penelitian ini, kegiatan yang dilakukan pada tahap pra-penulisan adalah setiap individu membuat kalimat pokok dari poster yang ada, yang dilanjutkan dengan kegiatan berkelompok untuk mendiskusikan kalimat pokok dari sebuah poster yang telah dibuat secara individu. Tahap penulisan, kegiatan individu dalam mengembangkan kalimat pokok menjadi karangan utuh yang bersifat persuasi, kemudian dilanjutkan tahap pasca penulisan yaitu penyuntingan hasil tulisan, terkait kesesuaian dengan topik

\footnotetext{
${ }^{20}$ Munadi, Y, Media Pembelajaran, (Jakarta: Gaung Persada, 2012), 102.

${ }^{21}$ Satrijono, H. Keterampilan Berbahasa Indonesia SD, (Jember: Fakultas Keguruan dan Ilmu Pendidikan Universitas Jember, 2011).

${ }^{22}$ Suparno, Keterampilan Dasar Menulis, (Jakarta: Departemen Pendidikan Nasional Universitas Terbuka, 2008).
} 
Wilda Ayu Hajar Octavia, Hari Satrijono, Fajar Surya Hutama, Dimas Abdi Haidar, Linda Purnamasari Rukmana

Keterampilan Menulis Karangan Persuasi Siswa Dalam Pembelajaran Think Talk Write

bahasan, kemampuan merangkai kalimat yang saling berkaitan satu sama lain, ketepatan dalam penulisan huruf kapital dan tanda baca, serta diakhiri dengan kegiatan membacakan hasil tulisannya di depan kelas.

Berdasarkan Standar Kompetensi (SK) dan Kompetensi Dasar (KD) pada pembelajaran Bahasa Indonesia kelas V SD, siswa harus mampu menuliskan karangan berdasarkan pengalaman dengan memperhatikan ejaan dan tanda baca ${ }^{23}$. Dengan demikian, siswa kelas V SD dituntut untuk mampu menulis dengan cermat, dengan memperhatikan penggunaan huruf kapital dan penempatan tanda baca.

Penelitian ini diawali dengan pemberian pre-test pada kelas kontrol dan kelas eksperimen, serta diakhiri dengan pemberian post-test dengan instrumen yang sama. Hasil pre-test dan post-test kemudian dianalisis menggunakan uji-t sebagai prasyarat dalam menerima $\mathrm{H}_{\mathrm{a}}$ dan $\mathrm{H}_{0}{ }^{24}$. $\mathrm{t}_{\text {hitung }}$ yang diperoleh adalah sebesar 2,208, sedangkan nilai ttabel pada taraf signifikansi 5\% adalah 2,0180. Jika kedua nilai ini dibandingkan maka didapat $t_{\text {hitung }}>t_{\text {tabel }}$, sehingga dapat diputuskan bahwa $\mathrm{H}_{\mathrm{a}}$ diterima dan $\mathrm{H}_{0}$ ditolak. Artinya, penerapan model pembelajaran Think Talk Write(TTW) melalui media poster berpengaruh signifikan terhadap keterampilan menulis karangan persuasi pada siswa kelas V SD.

Pelaksanaan model pembelajaran $T T W$ pada kelas eksperimen (VA) terbukti signifikan untuk meningkatkan keterampilan menulis karangan narasi persuasi siswa. Siswa dikelas eksperimen mengikuti kegiatan belajar menulis secara aktif dengan berfikir, berdiskusi, dan menyusun tulisan sehingga karangan narasi persuasi yang dihasilkan menjadi lebih baik. Secara berangsung-angsur penerapan model $T T W$ ini dapat meningkatkan keterampilan menulis karangan narasi persuasi siswa secara efektif. Hal ini

${ }^{23}$ Badan Standar Nasional Pendidikan, Kurikulum Tingkat Satuan Pendidikan Sekolah Dasar, (Jakarta: Badan Standar Nasional Pendidikan (BSNP), Departemen Pendidikan Nasional, 2006), 129.

${ }^{24}$ Masyhud, M. S, Metode Penelitian dan Pendidikan, (Jember: Lembaga Pengembangan Manajemen dan Profesi Kependidikan, 2016), 49. 
karena di dalam model TTW siswa secara bertahap didukung dalam memahami tata cara, aturan dan juga sistematika dalam menulis kalimat efektif melalui beberapa tahapan belajar ${ }^{25}$. sedangkan penerapan pembelajaran konvensional (VB) kurang dapat mengembangkan keterampilan menulis karangan siswa. Hal tersebut terjadi karena siswa di kelas kontrol hanya diberi penyajian materi-materi tentang menyusun karangan narasi tanpa mempraktekannya secara langsung untuk memahami penggunaannya.

Berdasarkan pembahasan di atas, dapat disimpulkan bahwa ada pengaruh yang signifikan dalam penerapan model pembelajaran Think Talk Write melalui media poster terhadap keterampilan menulis karangan persuasi pada siswa kelas V SDN Rambigundam 01 Jember. Hasil ini sesuai dengan sejumlah penelitian relevan sebelumnya, bahwa model pembelajaran Think Talk Write berpengaruh positif terhadap hasil belajar Bahasa Indonesia siswa $\mathrm{SD}^{26,27,28}$.

\section{SIMPULAN}

Berdasarkan hasil analisis dan pembahasan, maka dapat disimpulkan bahwa ada pengaruh yang signifikan dalam penerapan model pembelajaran Think Talk Write melalui media poster terhadap keterampilan menulis karangan persuasi pada siswa kelas V SDN Rambigundam 01 Jember. Hasil

\footnotetext{
${ }^{25}$ Aryananda, J., Chamistijatin, L., \& Hafi, A, Penerapan Model Think Talk Writeuntuk Meningkatkan Keterampilan Menulis Kalimat Efektif pada Siswa Kelas III SDN Sumbersari 1 Kota Malang, Jurnal Basicedu, (Vol. 3. No.1, 2019), 119.

${ }^{26}$ Prastiwi, D. Peningkatan Kemampuan Menulis Karangan Narasi Melalui Penerapan Model Pembelajaran Think Talk Write Berbantuan Media Gambar Berseri Siswa Kelas V SDN Sumbersari 03 Jember, Skripsi, (Jember: Universitas Jember, 2014).

${ }^{27}$ Dewi, Y., Sumantri, M., \& Riastini, P. Penerapan Model Pembelajaran Think Talk Write(TTW) Berbantuan Media Gambar Seri untuk Meningkatkan Keterampilan Menulis Karangan Siswa Kelas III SD, Skripsi, (Jember: Universitas Jember, 2016).

${ }^{28}$ Sugiarti, Y., Putra, A., \& Abadi, S, Pengaruh Model Pembelajaran TTW (Think Talk Write) Berbantuan Media Gambar Berseri Terhadap Keterampilan Menulis Bahasa Indonesia Siswa Kelas V SD Gugus 1 Kecamatan Kediri, e-journal MIMBAR PGSD, (Vol.2, No. 1, 2014), 9.
} 
Wilda Ayu Hajar Octavia, Hari Satrijono, Fajar Surya Hutama, Dimas Abdi Haidar, Linda Purnamasari Rukmana

Keterampilan Menulis Karangan Persuasi Siswa Dalam Pembelajaran Think Talk Write

perhitungan uji statistik independent sample test menunjukkan bahwa nilai thitung yang diperoleh adalah sebesar 2,208, sedangkan nilai ttabel pada taraf signifikansi 5\% adalah 2,0180. Jika kedua nilai ini dibandingkan maka didapat $t_{\text {hitung }}>t_{\text {tabel }}$, sehingga dapat diputuskan bahwa $\mathrm{H}_{\mathrm{a}}$ diterima dan $\mathrm{H}_{0}$ ditolak. Artinya, penerapan model pembelajaran Think Talk Write melalui media poster berpengaruh signifikan terhadap keterampilan menulis karangan persuasi pada siswa kelas V SDN Rambigundam 01 Jember. Hasil tersebut juga dapat dilihat berdasarkan peningkatan nilai keterampilan menulis karangan narasi siswa pada kelas eksperimen dan kelas kontrol. Selisih peningkatan nilai keterampilan menulis karangan narasi persuasi siswa di kelas eksperimen lebih tinggi terpaut 11,3 dibandingkan kenaikan nilai yang terjadi di kelas kontrol. Peningkatan tersebut dapat terjadi karena model pembelajaran Think Talk Write yang diterapkan mendukung siswa dalam mengikuti kegiatan belajar menulis secara aktif dengan berfikir, berdiskusi, dan menyusun tulisan sehingga karangan narasi persuasi yang dihasilkan menjadi lebih baik.

\section{DAFTAR PUSTAKA}

Aryananda, J., Chamistijatin, L., \& Hafi, A. Penerapan Model Think Talk Write untuk Meningkatkan Keterampilan Menulis Kalimat Efektif pada Siswa Kelas III SDN Sumbersari 1 Kota Malang. Jurnal Basicedu, Vol. 3, No.1, 2019.

Badan Standar Nasional Pendidikan. Kurikulum Tingkat Satuan Pendidikan Sekolah Dasar. Jakarta: Badan Standar Nasional Pendidikan (BSNP), Departemen Pendidikan Nasional, 2006.

Dery, D. W., Pebriana, P. H., \& Putra, K. E. Penerapan Model Kooperatif Tipe Think Talk Write untuk Meningkatkan Keterampilan Menulis 
Karangan Narasi Pada Siswa Sekolah Dasar. Jurnal Pendidikan dan Konseling, Vol. 1. No.1, 2019.

Dewi, Y., M. Sumantri., \& P. Riastini. Penerapan Model Pembelajaran Think Talk Write (TTW) berbantuan Media Gambar Seri untuk Meningkatkan Keterampilan Menulis Karangan Siswa Kelas III Sd. e-Journal PGSD, Universitas Pendidikan Ganesha, Vol. 4, No. 1 2016.

Haidar, D. A., Hasanah, S. A. \& Hutama, F. S. Analyzing Elementary Teacher's Understanding Towards Learning Instrument of 2013 Curriculum at SDN Sumbersari 1. Jember. Pancaran Pendidikan, Vol.6, No. 2, 2017.

Hamdayama, J. Model dan Metode Pembelajaran Kreatif dan Berkarakter. Bogor: Ghalia Indonesia, 2015.

Keraf, G. Argumentasi dan Narasi. Jakarta: Gramedia Pustaka Utama, 2000.

Masyhud, M. S. Metode Penelitian dan Pendidikan. Jember: Lembaga Pengembangan Manajemen dan Profesi Kependidikan, 2014.

Munadi, Y. Media Pembelajaran. Jakarta: Gaung Persada, 2012.

Prastiwi, D. "Peningkatan Kemampuan Menulis Karangan Narasi Melalui Penerapan Model Pembelajaran Think, Talk, Write (TTW) Berbantuan Media Gambar Berseri Siswa Kelas V SDN Sumbersari 03 Jember". Skripsi-Universitas Jember, 2014.

Rizal, M. S. Pengaruh Model Pembelajaran Kooperatif Tipe Think Talk Write (TTW) Terhadap Keaktifan dalam Pembelajaran IPS Kelas V SDN 20 Kuok. Jurnal Basicedu, Vol.2, No.1, 2018.

Ryanti, W. O. Penerapan Model Pembelajaran Think Talk Write (TTW) Untuk Meningkatkan Aktivitas dan Hasil Belajar Siswa Kelas V Pada Mata Pelajaran IPS SD Negeri 9 Metro Timur Tahun Pelajaran 2015/2016. Skripsi-FKIP Universitas Lampung, 2016.

Sadiman. Media Pendidikan. Jakarta: Rajawali Pers, 2010.

Satrijono, H. Keterampilan Berbahasa Indonesia SD. Jember: Fakultas Keguruan dan Ilmu Pendidikan Universitas Jember, 2011.

Siddiq, dkk. Pengembangan Bahan Pembelajaran SD. Jakarta: Direktorat Jenderal Pendidikan Tinggi Departemen Pendidikan Nasional, 2008.

Sugiarti, Y., A, Putra., \& S, Abadi. Pengaruh Model Pembelajaran TTW (Think Talk Write) Berbantuan Media Gambar Berseri terhadap Keterampilan Menulis Bahasa Indonesia Siswa Kelas V SD Gugus 
Wilda Ayu Hajar Octavia, Hari Satrijono, Fajar Surya Hutama, Dimas Abdi Haidar, Linda Purnamasari Rukmana

Keterampilan Menulis Karangan Persuasi Siswa Dalam Pembelajaran Think Talk Write

1 Kecamatan Kediri. e-Journal MIMBAR PGSD Universitas Pendidikan Ganesha Jurusan PGSD, Vol. 2 No. 1, 2014.

Suparno. Keterampilan Dasar Menulis. Jakarta: Departemen Pendidikan Nasional Universitas Terbuka, 2008.

Susanto, A. Teori Belajar dan Pembelajaran di Sekolah Dasar. Jakarta: Kencana Prenada Media Group, 2015.

Tarigan, H. Menulis sebagai suatu Keterampilan Berbahasa. Bandung: Penerbit Angkasa, 1994.

Yusron. Cooperative Learning. Bandung: Nusa Media, 2005. 